\title{
Wage setting in Slovenia: interpretation of the Wage Dynamics Network (WDN) survey findings in an institutional and macroeconomic context
}

\author{
${\text { Biswajit Banerjee }{ }^{1 *}, \text { Matija Vodopivec }^{2} \text { and Urban Sila }}^{3}$
}

\footnotetext{
* Correspondence: bisban50@gmail. com

${ }^{1}$ Haverford College, Haverford, PA, USA

Full list of author information is available at the end of the article
}

Abstract: This paper examines responses to questions on wage setting features in Slovenia's Wage Dynamics Network (WDN) survey in the institutional and macroeconomic context of the Slovene economy. The question on collective wage agreement did not capture the prevailing institutional arrangement of multi-level agreements, and the responses on wage indexation were seemingly at odds with institutional features of wage setting. Labor cost adjustments during the financial crisis were primarily in variable pay components and employment but not in base wages. Minimum wage policy contributed to downward wage rigidity.

JEL codes: D22, J31, J38, J50

Keywords: Wage rigidity; Collective bargaining; Indexation; WDN survey; Slovenia

\section{Introduction}

Labor market institutions and wage setting mechanisms in euro area countries have recently received considerable attention from the European System of Central Banks (Eurosystem). In a monetary union, countries do not have the option of using exchange rate policy to respond to shocks and the importance of wage and labor market flexibility as adjustment mechanisms becomes greater. If significant institutional rigidities are present, wage developments can perpetuate or exacerbate inflationary pressures and render the task of macroeconomic stabilization yet more difficult. Furthermore, if the rigidities are different across member countries, even common shocks may lead to persistent differences in labor costs and associated changes in competitiveness. Thus, a proper understanding of the features of labor market and wage rigidities is essential for designing appropriate structural policies that will facilitate adjustment to shocks.

With these considerations in mind, the Eurosystem established the Wage Dynamics Network (WDN) research group in July 2006 to conduct an in-depth study of the sources and features of wage and labor cost dynamics, and of the relationship between wages, labor costs and prices both at the firm and macroeconomic level. Key elements of this research were two questionnaire-based surveys conducted in late 2007/early 2008. One survey questionnaire, filled out by experts from national central banks in 23 European countries ${ }^{1}$, was aimed at collecting information on wage bargaining institutions that prevailed in 2006 and a decade earlier in 1995 ${ }^{2}$. The second survey 
questionnaire sought information on wage and price-setting behavior at the firm level, and was filled out by firms in 17 European countries. The harmonized questionnaire included a common set of "core" questions for all countries, but some countries adapted the questionnaire to account for specific country characteristics and differences in institutional framework by including fewer or additional "non-core" questions ${ }^{3}$. A third follow-up WDN survey was conducted during the summer of 2009 in a sample of 10 countries to examine firms' perception of the financial crisis and their actual responses to it.

Ad hoc surveys typically have shortcomings. The most common limitations are a low response rate and respondent bias (European Central Bank 2009a). The latter includes recall error, lack of familiarity with the details, misunderstanding in interpreting the questions, and being influenced by the specific macroeconomic environment prevailing at the time of the survey. Therefore, it would be of interest to examine how well the survey responses conform to known institutional features of wage setting and macroeconomic developments in the country. This issue has not received much attention in the discussions of the WDN survey results. In this paper, we carry out such an exercise based on responses to selected questions on features of wage setting in the 2008 WDN firm-level survey for Slovenia. Slovenia did not participate in the follow-up 2009 WDN survey.

This paper provides a description of wage setting institutions in Slovenia, places the labor market outcomes in a broader macroeconomic context, and presents selected results of the 2008 firm-level WDN survey. The primary objective of the paper is to check the survey results for consistency and signal potential caveats in its interpretation, including with regard to downward real wage rigidity. An important conclusion of the paper is that the WDN survey findings for Slovenia have to be interpreted with care, owing to limitations in both the design of the survey questionnaire and its implementation in practice. The paper makes suggestions regarding the conduct of a followup survey of Slovene firms, which would address some of the limitations of the 2008 survey and would also allow a better understanding of wage setting practices in different phases of a business cycle.

The paper is organized as follows. Section 2 looks at the evolution of collective bargaining and wage setting institutions in Slovenia. Section 3 discusses the developments in GDP growth, inflation, labor productivity, and average wages during 1995-2010. Section 4 reviews selected findings of the WDN survey and econometric analysis of wage rigidity, against the backdrop of the discussion of wage-setting institutions and macroeconomic developments. Section 5 concludes.

\section{Some institutional features of wage setting}

Analyses of labor market institutions typically examine, inter alia, union density, the level of collective bargaining, the coverage of collective wage agreements, degree of wage indexation, and developments in minimum wages. Researchers generally consider centralization of wage bargaining and higher values of the other indicators as evidence of less flexibility (e.g., see Deutsche Bundesbank 2009; Kézdi and Kónya 2009). In Slovenia, some of the individual aspects of institutions have become more flexible over time. However, one should be careful in drawing conclusions about the effect of this on 
macroeconomic performance. As Aidt \& Tzannatos (2002) note, the impact of individual aspects such as union density or centralization of bargaining cannot be assessed in isolation as it is the package of institutions that matters. In addition, the impact depends on the prevailing economic, legal, and political environment and can vary over time.

\subsection{Trade union density}

Trade union density in Slovenia has decreased since independence, though different data sources disagree on the extent of the decline in recent years. According to European Industrial Relations Observatory On-line (EIROnline) (2004, 2009a, 2009b), the percentage of employees affiliated with a trade union decreased by about one third in the initial years of Slovenia's transition to a market-oriented economy from 63.5 percent in 1994 to 42.8 percent in 1998, and fluctuated between 40 and 44 percent thereafter ${ }^{4}$. In contrast, the OECD data base shows a much lower level of union density and a large fall in recent years. According to the OECD, union density in Slovenia fell from 37.5 percent in 2003 to 28.1 percent in 2008 and 25.6 percent in 2009 (http://stats.oecd.org/Index.aspx? DataSetCode=UN_DEN) It is believed that union density declined further during 20102011 as a result of the crisis-related rise in bankruptcies (European Industrial Relations Observatory On-line (EIROnline) 2013).

The decline in union density in Slovenia can be explained by the structural changes in the economy during the transition process and run-up to euro adoption. Sectors with traditionally high union density (e.g., mining, textiles, leather, and basic metals) have undergone substantial downsizing, and employment growth has mainly taken place in the services sectors where union representation is smaller and more difficult to organize. In addition, the practice of hiring workers on fixed-term contracts or recruiting temporary workers through employment agencies has become more prevalent ${ }^{5}$, and such workers have little incentive to join trade unions (European Industrial Relations Observatory On-line (EIROnline) 2010).

\subsection{Level and coverage of collective bargaining}

Notwithstanding a decrease in trade union density, virtually all employees in Slovenia have been covered by collective agreements over the years. In 2007, 96 percent of employees were covered by collective agreements and the remaining 4 percent of employees, comprising of managerial workers, were covered by individual agreements (European Industrial Relations Observatory On-line (EIROnline) 2009b). Until 2005, the extension procedure of collective agreements was based on "functional equivalent", in that because of compulsory membership of enterprises in the Chamber of Commerce and Industry the agreements were binding for all employers and their employees (Institute of Macroeconomic Analysis and Development (IMAD) 2004). Membership in employers' associations ceased to be compulsory from 2006, but the Collective Agreements Act 2006 stipulated that sectoral agreements concluded by associations of employers would continue to be mandatory for all employers and their employees in the sector for a transitional period of three years. Thereafter, the Act allows for the possibility of extension of a sectoral collective agreement to all employers and employees in the sector if the agreement was signed by representative trade unions and employers 
that employ at least 50 percent of all employees in the sector and one of the parties seek an extension from the Minister of Labor (European Industrial Relations Observatory On-line (EIROnline) 2009c); European Foundation for the Improvement of Living and Working Conditions (Eurofound) 2011) ${ }^{6}$. During 2009-2010, the Minister of Labor granted extension to six sectoral collective bargaining agreements.

Wage bargaining in Slovenia in the private sector is highly structured and are negotiated at three levels ${ }^{7}$. A general agreement at the national level determines the wage indexation mechanism that is binding for the entire private sector, while sectoral and enterprise-level agreements negotiate additional wage increases based on productivity growth, financial performance, and other considerations. Agreements at each of the lower levels normally improve on the provisions of the higher level agreements. However, the higher level agreements generally include escape clauses that allow enterprises in financial distress to defer specified wage increases under certain conditions.

A move toward partial decentralization of the bargaining framework was initiated in 2006 but the changes did not fully go into effect immediately. The Collective Agreement Act 2006 provided for collective agreements to be negotiated on a voluntary basis, but the prevailing practice of full coverage of general and sectoral agreements was to remain in effect for a three-year transitional period. Until 2005, the general agreement at the national level was negotiated on a tripartite basis between the trade unions, employers and government. From 2006 onward, the government stopped participating in the negotiations. Collective bargaining at the sectoral level gained in importance and became dominant. However, the social partners continued to negotiate a general agreement on starting pay and minimum basic pay increases as well as inflation safeguard clause that would apply to all workers in the private sector who were not covered by sectoral collective agreements or whose sectoral collective agreement did not determine the pay adjustment supplement. The sectoral agreements were required by law to set terms at least as favorable as those in the general intersectoral agreement ${ }^{8}$.

There has been no new general intersectoral collective agreement since the expiry of the 2008-2009 general intersectoral collective agreement in December 2010, and all pay-related issues for the private sector are being regulated by the Employment Relationship Act and sectoral collective agreements. In some sectors-especially the laborintensive ones like textiles, clothing, and leather industries-collective bargaining has stopped altogether because of the adverse impact of the economic crisis. However, wages in these sectors have been adjusted in line with the increase in the minimum wage (European Industrial Relations Observatory On-line (EIROnline) 2013).

Enterprise-level collective agreements always have been voluntary and are over and above the provisions of general and sectoral agreements. Thus, enterprises have flexibility to react to enterprise-specific economic circumstances, subject to meeting the norms set in the general and sectoral agreements. Enterprise-level agreements are more common in large firms. According to employers' associations, about 75-80 percent of large enterprises, 20-50 percent of medium-sized enterprises and less than 10 percent of small enterprises are covered by enterprise-level collective agreements ${ }^{9}$. The estimates of trade union confederations are lower. The two largest trade union confederations (ZSSS and KS - 90) estimate that 30-50 percent of large enterprises, 20-30 percent of medium-sized enterprises and 5 percent of small enterprises are covered by 
enterprise-level collective bargaining (see Table twelve in European Foundation for the Improvement of Living and Working Conditions (Eurofound) 2007). There are no estimates on how enterprise-level collective agreements have evolved over time.

\subsection{Indexation of wages to inflation}

Adjustment of wages to inflation has been a key element of all general wage agreements in Slovenia (Table 1). The indexation mechanism has been modified periodically to support disinflation during the transition process and run-up to euro adoption. During 1995-2000, the indexation mechanism was backward looking, with base wage increases partially indexed to past inflation. In 2001, social partners agreed to the implementation of a forward-looking indexation mechanism which provided for partial indexation of base wage increases to the projected inflation rate and a safeguard for additional increase in the event actual inflation turned out to be higher than projected. The indexation mechanism was further modified in 2004, coinciding with Slovenia's membership of the European Union and entry in the Exchange Rate Mechanism II in preparation for euro adoption. The new indexation formula tied wage increases to projected inflation in Slovenia, projected inflation in selected EU member states, and the projected exchange rate of the tolar vis-à-vis the euro. The mechanism also included a safeguard for additional wage increase in the event actual inflation exceeded a specified rate.

The general agreements reached by social partners in 2006 and 2008 without government participation continued to link wage increases to inflation. Projected inflation was taken into account in the determination of the increase in starting and minimum base wages, though this was not transparent as the agreements proposed increases of a specified percentage each year. Both agreements also included a provision for additional wage increases if inflation exceeded a specified rate.

The frequency of wage adjustments initially depended on the pace of inflation, but has not varied in recent years. Adjustments were made quarterly during 1995-96 when inflation was high. As inflation slowed down, adjustments were made once a year during 1997-98. However, with the resurgence of inflation pressure in 1999 wage adjustments began to be carried out twice a year and this frequency of adjustment continued to be provided for in the wage agreements for subsequent years even after inflation came down ${ }^{10}$.

\subsection{Minimum wages}

Minimum wage developments have contributed to downward wage rigidity in Slovenia. Until 2006, the minimum wage was set within the framework of the tripartite agreement between unions, employers and the government. Since then, the government has been setting the minimum wage alone, following consultations with employers and unions. During 2001-2004 and 2008-2010 the minimum wage went up by more than the average wage in the private sector. Thus, the ratio of the minimum wage to the average wage in the private sector has risen from 43 percent in 2000 to 48 percent in 2010, with a temporary dip during 2006-2007 (Figure 1). Following its increase in March 2010, the minimum wage rather than the basic wage negotiated in sectoral collective agreements became the binding wage-setting parameter for many workers in the private sector, and there was a leveling out of wages at the bottom half of the wage 
Table 1 Slovenia: Wage policy under general/inter-sectoral collective agreements for private sector employees

\begin{tabular}{|c|c|c|}
\hline $\begin{array}{l}\text { Date of } \\
\text { agreement }\end{array}$ & Type of agreement & Features of wage agreement \\
\hline \multirow[t]{4}{*}{1995} & \multirow[t]{4}{*}{ Social agreement } & Overall objective: maintain level of real wages. \\
\hline & & $\begin{array}{l}\text { Quarterly adjustment of base wages by } 85 \% \\
\text { of inflation in the previous quarter. }\end{array}$ \\
\hline & & $\begin{array}{l}\text { Additional increase in wages related to } \\
\text { productivity }\end{array}$ \\
\hline & & $\begin{array}{l}\text { Overall objective: maintain level of real } \\
\text { wages. }\end{array}$ \\
\hline \multirow[t]{3}{*}{1996} & \multirow[t]{3}{*}{ Social agreement } & $\begin{array}{l}\text { Overall objective: maintain level of real } \\
\text { wages. }\end{array}$ \\
\hline & & $\begin{array}{l}\text { Quarterly adjustment of base wages by } \\
85 \% \text { of inflation in the previous quarter. }\end{array}$ \\
\hline & & $\begin{array}{l}\text { Additional increase in wages related to } \\
\text { productivity. }\end{array}$ \\
\hline \multirow[t]{2}{*}{ 1997, June } & \multirow[t]{2}{*}{$\begin{array}{l}\text { Pay policy agreement for } \\
1997-1999\end{array}$} & $\begin{array}{l}\text { Quarterly indexation of base wages } \\
\text { replaced by annual indexation. }\end{array}$ \\
\hline & & $\begin{array}{l}\text { Base wages to increase by } 85 \% \text { of inflation } \\
\text { in previous year. }\end{array}$ \\
\hline \multirow[t]{6}{*}{1999} & \multirow{6}{*}{$\begin{array}{l}\text { Agreement on Incomes } \\
\text { Policy for } 1999-2001\end{array}$} & 1999 - 2000: \\
\hline & & $\begin{array}{l}\text { Adjustment of base wages in January by } 85 \% \\
\text { of inflation in previous year. }\end{array}$ \\
\hline & & $\begin{array}{l}\text { Additional increase in mid-1999 for price } \\
\text { impact of introduction of VAT. }\end{array}$ \\
\hline & & $\begin{array}{l}\text { Safeguard clause for additional increase in } \\
\text { mid-2000 in the event of higher-than-expected } \\
\text { inflation. }\end{array}$ \\
\hline & & 2001: \\
\hline & & $\begin{array}{l}\text { Gradual transition to forward-looking } \\
\text { indexation of base wages. }\end{array}$ \\
\hline
\end{tabular}

Base wages increased in July 2001 by $92.5 \%$ of inflation in first half of year.

Base wages to increase in January 2002 by $90 \%$ of projected inflation in second half of 2001 (equivalent to increase of $2.7 \%$ )

Safeguard clause for additional increase in the event of higher-than-projected inflation.

Base wages to be adjusted two times a year, based on projected inflation.

August 2002: Base wages to increase by $4.2 \%$.

December 2002: Base wages to increase by amount that inflation during January-November 2002 exceeds $4.2 \%$.

August 2003: Base wages to increase by $2.5 \%$ plus the amount that inflation during January-June 2003 exceeds 2.6\%. (The additional increase to be triggered only if actual inflation during January-June exceeds 2.8\%).

December 2003: Base wages to increase by the amount that inflation during January-November 2003 exceeds the wage increase awarded in August. 
Table 1 Slovenia: Wage policy under general/inter-sectoral collective agreements for private sector employees (Continued)

\begin{tabular}{|c|c|c|}
\hline & & \multirow{2}{*}{$\begin{array}{l}\text { tolar-euro exchange rate. The formula resulted in } \\
\text { wage increases of } 3.2 \% \text { in } 2004 \text { and } 2.7 \% \text { in } 2005 \text {. } \\
\text { Additional wage increase by the amount that actual } \\
\text { inflation in Slovenia exceeds 3.6\% during } \\
\text { December } 2003 \text { - December } 2004 \text { and } 2.9 \% \\
\text { during December } 2004 \text { - December } 2005 \text {. }\end{array}$} \\
\hline & & \\
\hline & & $\begin{array}{l}\text { All workers to receive minimum wage increase of SIT } \\
5,000 \text { in August } 2004 \text { and SIT 5,100 in August } 2005 \text {. }\end{array}$ \\
\hline & & $\begin{array}{l}\text { Additional wage increases related to productivity } \\
\text { gains possible in sectoral collective agreements, } \\
\text { subject to the condition that overall real growth } \\
\text { in average wages should lag productivity growth } \\
\text { by at least one percentage point. }\end{array}$ \\
\hline 2005, September & GCAPS & $\begin{array}{l}\text { Cancelled by Employers' Associations in anticipation } \\
\text { of new framework of collective agreements being } \\
\text { negotiated without government participation. }\end{array}$ \\
\hline \multirow[t]{3}{*}{ 2006, June } & \multirow{3}{*}{$\begin{array}{l}\text { Inter-sectoral collective } \\
\text { agreement (CAMPA), } \\
\text { July } 2006 \text { - December } 2007\end{array}$} & $\begin{array}{l}\text { Starting wage and minimum base wage to increase } \\
\text { by } 2 \% \text { in } 2006 \text { and in } 2007 .\end{array}$ \\
\hline & & $\begin{array}{l}\text { Further increase in base wage in August } 2007 \text { by } \\
\text { the amount that actual inflation during } \\
\text { December } 2005 \text { - December } 2006 \text { exceeded } \\
\text { the forecast inflation rate of } 2.3 \% \text {. }\end{array}$ \\
\hline & & $\begin{array}{l}\text { Social partners can agree on higher than } 2 \% \text { wage } \\
\text { increase at the enterprise level, if justified by } \\
\text { productivity growth. }\end{array}$ \\
\hline \multirow[t]{4}{*}{ 2008, May } & \multirow[t]{4}{*}{$\begin{array}{l}\text { Intersectoral collective } \\
\text { agreement, } 2008-2009\end{array}$} & $\begin{array}{l}\text { No further base wage increases in enterprises that } \\
\text { already increased base wage by } \geq 5.2 \% \text { in } 2007 \text {. }\end{array}$ \\
\hline & & $\begin{array}{l}\text { Enterprises which increased base wage by }<5.2 \% \\
\text { in } 2007 \text { to increase wages in May } 2008 \text { by difference } \\
\text { between actual wage increase and } 5.2 \% \text { threshold. }\end{array}$ \\
\hline & & $\begin{array}{l}\text { Starting and lowest base wage to to increase by } \\
3.9 \% \text { in August } 2008 \text { and } 2.3 \% \text { in August } 2009 \text {. }\end{array}$ \\
\hline & & $\begin{array}{l}\text { Safeguard clause: Full adjustment in January } 2009 \\
\text { for inflation exceeding 4.55\% in 2008. Full adjustment } \\
\text { in January } 2010 \text { for inflation exceeding } 2.7 \% \text { in } 2009 .\end{array}$ \\
\hline
\end{tabular}

tolar-euro exchange rate. The formula resulted in wage increases of $3.2 \%$ in 2004 and $2.7 \%$ in 2005 .

Sources: EIROnline (various issues), Institute of Macroeconomic Analysis and Development (IMAD) (2007a, 2007b).

tariff scale. In 2010, the level of the minimum wage stood mostly at the level of the fifth tariff class (the seventh tariff class in the textile sector) compared with the lowest basic and starting wages set in collective bargaining agreements (Institute of Macroeconomic Analysis and Development (IMAD) 2011). Prior to 2010, the minimum wage was binding for all sectoral collective agreements in the first tariff class. The share of minimum wage recipients in total employment jumped from 2.8 percent in 2009 to 5.5 percent in 2010.

\section{Macroeconomic background}

Slovenia experienced a robust economic growth until the onset of the global financial crisis in 2008. Real GDP growth fluctuated around an average of about 4 percent during 1996-2005, rose sharply during 2006-07, and fell markedly thereafter (Figure 2). Being a small open economy, Slovenia's growth was highly sensitive to the external economic environment. The periods of slowdown of economic growth coincided with unfavorable external conditions. GDP growth was primarily driven by productivity growth 


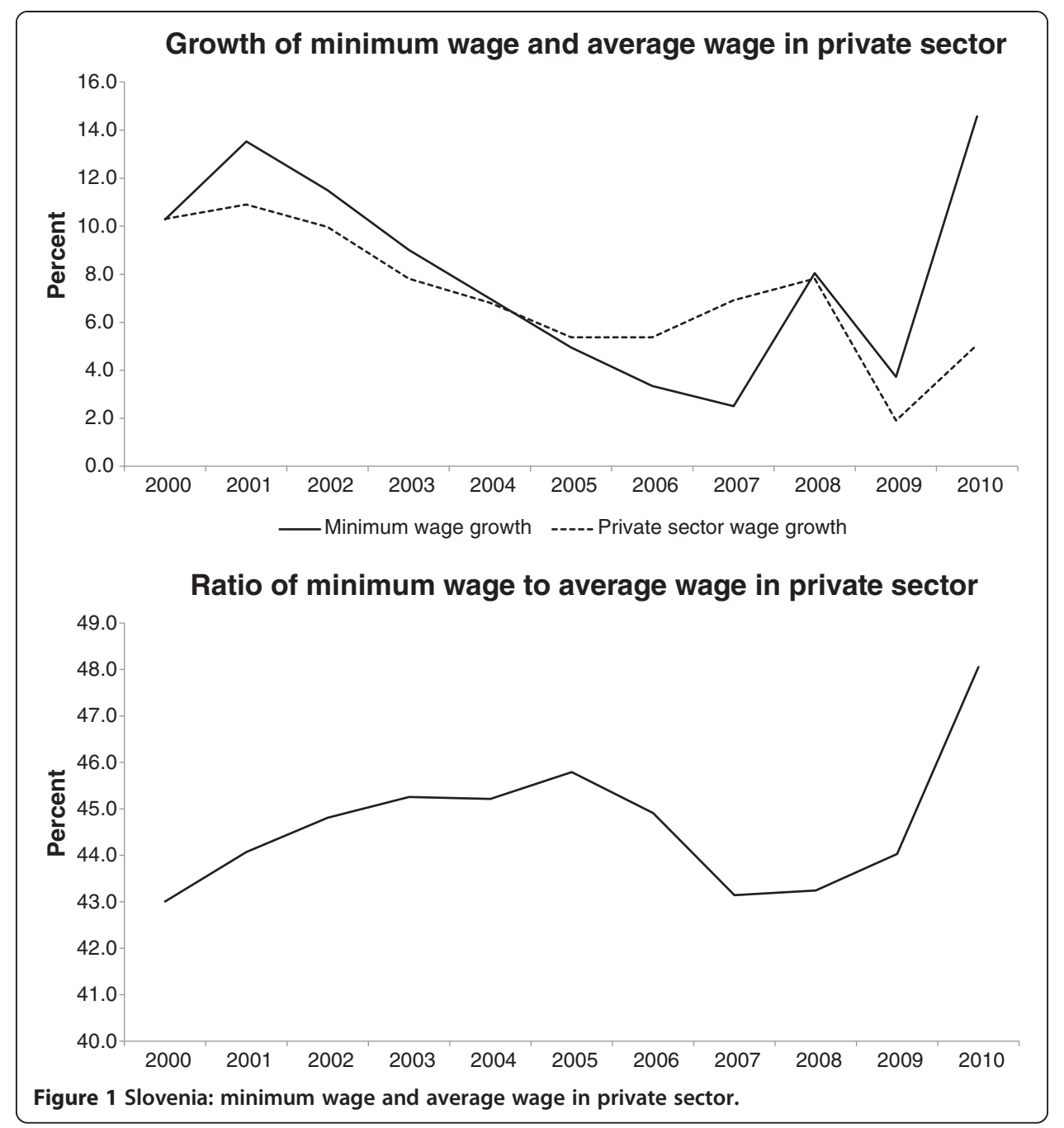

throughout, though the influence of employment growth on GDP growth picked up during 2007-08.

Inflation followed a broad downward trend until 2006, but turned around in 2007-08 and came down sharply in 2009 as the impact of the global financial crisis began to be felt. The pickup in inflation following euro adoption in 2007 was unanticipated. With inflation having bottomed out at 2.5 percent in 2005-06, the Autumn 2006 official forecast for annual average inflation in 2007 and 2008 was 2.7 percent and 2.5 percent respectively (Institute of Macroeconomic Analysis and Development (IMAD) 2006). However, actual inflation rose to 3.6 percent in 2007 and 5.7 percent in 2008, in part reflecting faster-than-potential economic growth and an associated rising positive output gap ${ }^{11}$.

Wage policy is generally considered to have facilitated the disinflation process in Slovenia during the transition process and run-up to euro adoption in 2007 (Bole and Mramor 2006; Banerjee and Shi 2010). As noted earlier, adjustments of basic wages to inflation were always partial and the wage indexation formula was weakened from 2001 onward. However, for a complete picture one should focus on the total gross wage of a worker rather than basic wage, and compare the dynamics of nominal and real total 


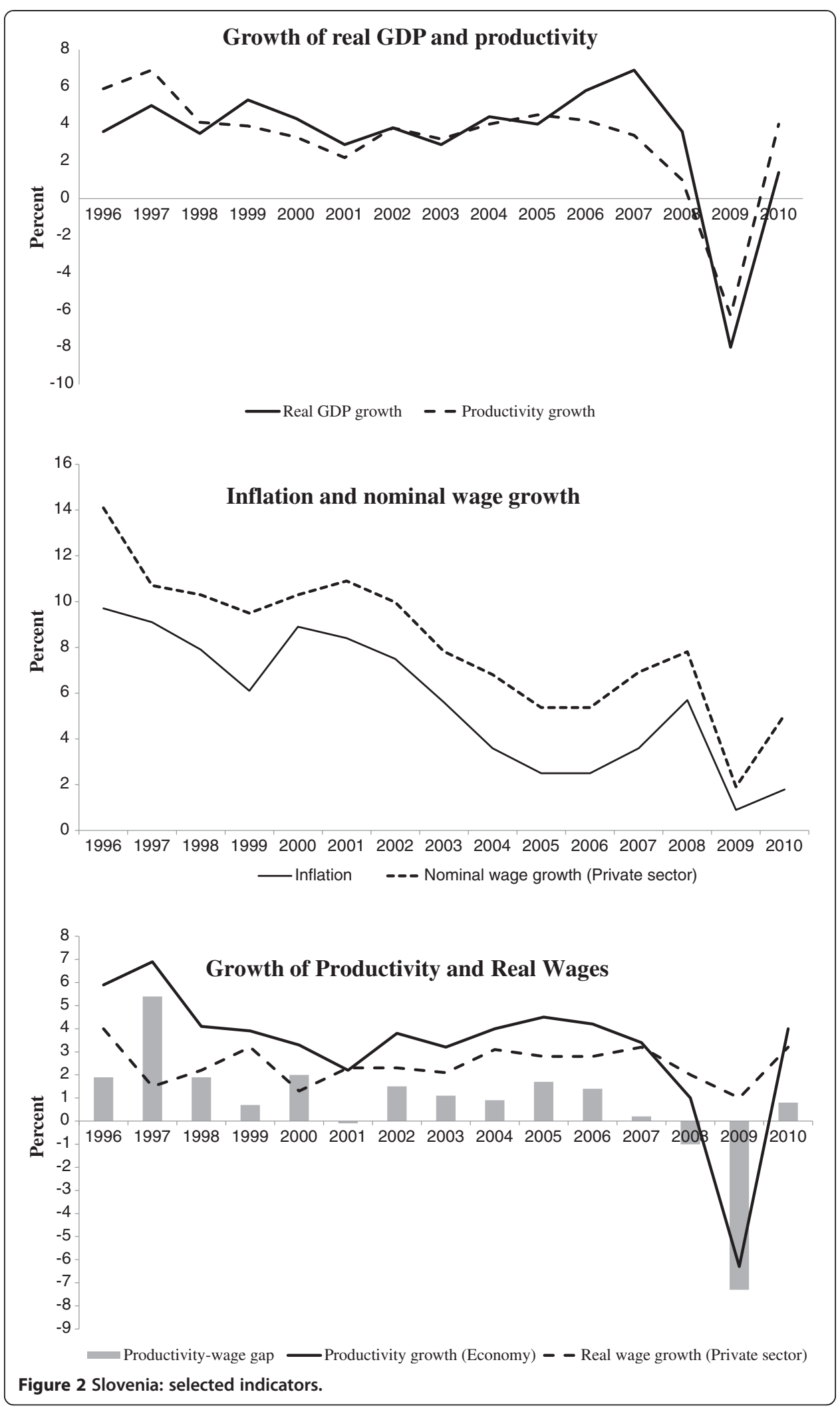


gross wage with that of productivity. The increase in the total gross wage of a worker depends on the increase in basic wage, increases negotiated in sectoral and enterprise-level collective agreements, and other increases based on promotions, individual performance, and enterprise performance. Thus, the growth of total gross wage may exceed inflation. Whether or not this adds to inflationary pressures depends on the trend in the growth of unit labor costs (ULC).

As Figure 2 shows, nominal wage growth in the private sector in Slovenia exceeded inflation in all years, implying a positive real wage growth. Real wage growth averaged around 2 percent during 1997-2003 and around 3 percent during 2004-2007. The pace slowed down with the onset of the financial crisis and reached a low of 1 percent in 2009, before recovering to the pre-crisis rate in 2010. A part of the nominal (and, hence, real) wage growth during 2009-2010 reflected a "composition" effect of a changed employment structure resulting from layoffs of workers with low educational attainment and low wages. The layoffs of low-paid workers tend to statistically raise the average wage level even if wages of workers who retain their jobs do not increase. It is estimated that the "composition" effect accounted for 0.9 percentage points of the 1.8 percent increase in the average nominal wage in the private sector in 2009, and 0.5 percentage points of the 5.1 percent increase in the average nominal wage in 2010. A bulk (3 percentage points) of the increase in average nominal wage in 2010 can be attributed to the rise in the minimum wage. Excluding the "composition" effect and the impact of the rise in the minimum wage, the remaining effects $(0.9$ percentage points in 2009 and 1.6 percentage points in 2010) point to a substantial slowdown in wage growth with the onset of the economic crisis (Institute of Macroeconomic Analysis and Development (IMAD) 2011, 2012). In response to the deteriorating economic situation, employers cut back paid overtime work and reduced the amount of $13^{\text {th }}$-month payments (European Industrial Relations Observatory On-line (EIROnline) 2009b) ${ }^{12}$.

In contrast to the pattern in the pre-crisis years, real wage growth rose at a faster rate than productivity growth in 2008-09. One should not immediately interpret the emergence of a negative gap between productivity growth and wage growth as evidence of wage rigidity during an economic downturn. When faced with a decline in demand, employers have the option of cutting total labor costs through adjustments in wages as well as employment. During the economic crisis, enterprises did reduce employment but probably by less than what they might have had, if it were not for the measures that were introduced by the Slovene government aimed at encouraging enterprises to keep workers on their payroll. These measures included subsidies for shorter-hour work schedule and for giving workers paid leave for a temporary period ${ }^{13}$. Because of the anti-crisis measures to avoid redundancies, measured productivity declined sharply in 2009 and a large negative productivity-wage gap emerged.

In practically all general collective agreements, social partners had implicitly or explicitly agreed that real wage growth should lag behind productivity growth ${ }^{14}$. This guideline was abided by a margin of close to 1 percent or more in all years, except 2001 and 2008-09. Reflecting this, real ULC was on a declining trend until 2007, but rose appreciably during 2008-09 (Figure 3). Nominal ULC was on a rising trend throughout. The pace slowed progressively during 2002-05, but picked up sharply during 2007-09 on account of both faster nominal wage growth and slower or negative productivity growth. 


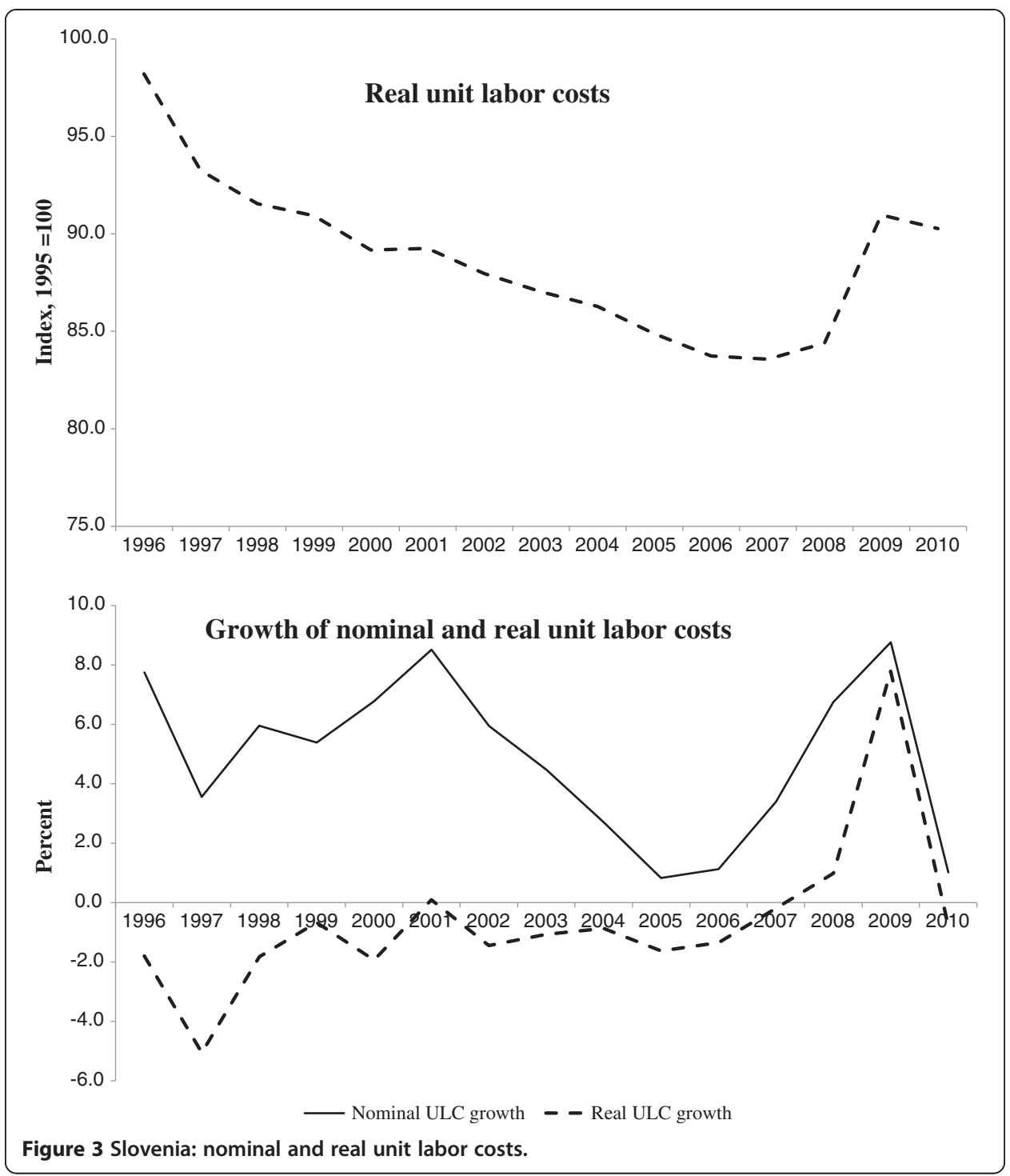

Calmfors and Driffill (1988) have hypothesized a humped-shaped relationship between wage bargaining systems and economic performance: that real wage growth is lower under highly centralized (national level) and highly decentralized (firm level) wage bargaining systems and higher under an intermediate (industry level) bargaining system. As cited earlier in Section 2, the impact of individual aspect of degree of bargaining cannot be assessed in isolation as it is the package of institutions that matters. Thus, it is difficult to assess the impact of the changes in the collective bargaining mechanisms on real wage outcomes in Slovenia, given the multiple levels of bargaining in operation, continued practice of extension of collective agreements to all workers, shock of the economic crisis, adaptability of union-employer coordination to the crisis situation, and downward wage rigidity imposed by minimum wage policy. The short observation period does not allow us to carry out a meaningful multivariate analysis. Further, Driffill (2006) notes that the empirical analysis of Calmfors and Driffill has been criticized for having paid more attention to the level at which bargains were 
struck and less to the extent of coordination among participants to wage setting (which seems to be an important consideration in Slovenia).

\section{Selected findings of the Wage Dynamics Network survey}

The WDN survey in Slovenia was conducted in January-February 2008, and the reference period was $2006^{15}$. A sample of 3,000 non-agricultural private-sector enterprises with 5 or more employees was selected from the Business Register of Slovenia using a stratified sampling technique. The stratification was done by sector (two-digit NACE classification) and firm size (less than 50 employees, 50-199 employees, and 200 employees or more). The selected firms were contacted by mail with instructions to fill out a web-based questionnaire. Only 681 enterprises, or 22.7 percent of those that were contacted, filled out the questionnaire. The response rate varied considerably across sectors and firm-size groups. The proportion responding to the survey was lowest among small-sized enterprises (16 percent) and among enterprises in tourism (12 percent) and construction (13.5 percent). Thus, in order to adjust for the unequal probability of enterprises ending up in the final sample and to make the results applicable to the entire population of workers, the survey responses were scaled by employmentadjusted sampling weights.

The Slovenia survey conformed closely to the template provided by the WDN. It included the core and optional questions of the WDN plus some questions that were specific to Slovenia and not included in the other national questionnaires. The questions were qualitative and quantitative in nature and were aimed at obtaining an understanding of the features of wage setting and price and wage dynamics. In particular, the survey included questions on the frequency of wage changes, time-dependence and synchronization of wage changes, prevalence and features of indexation and adjustment of wages to inflation, wage setting of new hires, downward wage rigidity, response of wages to shocks, the synchronization of wage and price changes, and how wages feed into prices. Unfortunately, the Slovenia questionnaire did not include a question relating to minimum wages. More details on the WDN survey in Slovenia and the questionnaire can be found in Sila and Jesenko (2011) and Vodopivec (2010).

The assessment of the survey responses in this paper is selective. In particular, we review only the responses on collective agreement coverage, adjustment of base wages to inflation, wage rigidity, and labor cost adjustment strategies. We do not discuss the survey responses related to behavior of wages of newly hired employees and to price and wage dynamics.

\subsection{Level of collective wage agreement}

The question on the level of collective wage agreement was posed differently in the Slovenia survey from that in the WDN survey in other countries and had a major shortcoming. In other countries, the survey included two questions on this issue: if the firm applied a collective wage agreement set outside the firm and, irrespective of the answer to this question, if the firm applied a wage agreement signed at the firm level. Thus, these surveys could capture collective agreements being applied at more than one level. In contrast, the Slovenia survey only asked which level of collective bargaining agreement was applied by the firm, and did not provide the option of 
recording multiple answers. Thus, the survey did not capture the application of more than one level of agreement that we know from Section 2 was a standard feature of the Slovene system. This shortcoming needs to be taken into account in interpreting the responses to the question on the level of collective bargaining that applied.

According to the WDN survey, about one-fourth of non-agricultural private sector employees in Slovenia were covered by firm-level collective agreements, slightly more than one-half by sectoral collective agreements, and one-fifth by general collective agreement (Table 2). Since we know from Section 2 that in the reference year 2006 (i) a general agreement covered a small group of workers not covered by relevant sectoral agreements for a variety of reasons, and (ii) firm-level collective agreements were voluntary and augmented the agreements at the general and sectoral levels, it seems reasonable to infer that the response of the firms in the survey probably indicate the lowest-level of collective agreement that they applied. However, because the survey did not allow for multiple responses, we cannot accurately ascertain the importance of different levels of agreement from the survey responses and cannot unequivocally compare the findings for Slovenia with those for other countries.

As Table 2 shows, there were significant differences between firm-size groups and sectors in the application of different levels of collective agreement. Firm level wage agreements were applied most frequently by firms with 200 or more workers and by firms in the utilities sector. Firms in manufacturing and financial intermediation also reported incidence of firm-level wage agreements above the national average. The application of general level agreement was reported most frequently by firms employing less than 50 workers and by firms in market services. The patterns by firm-size and sectors were consistent with expectations and broadly in line with that observed in some western European countries (see Deutsche Bundesbank 2009; European Industrial Relations Observatory On-line (EIROnline) 2009a; Montornès and Sauner-Leroy 2009).

Table 2 Slovenia: Level of collective wage agreement by firm size and sector (Percent in each size group and sector) ${ }^{a}$

\begin{tabular}{lcccccc}
\hline & \multicolumn{5}{c}{ Level of agreement } \\
\cline { 2 - 7 } & General level & Sector level & Firm level & Don't know & Other & Total \\
\hline Firm size (number of employees) & & & & & & \\
5 to 19 & 44.1 & 40.9 & 9.5 & 2.0 & 3.5 & 100.0 \\
20 to 49 & 37.7 & 42.6 & 17.4 & - & 2.4 & 100.0 \\
50 to 199 & 9.5 & 76.6 & 13.9 & - & - & 100.0 \\
200 or more & 7.6 & 52.1 & 38.6 & - & 1.7 & 100.0 \\
All size groups & 19.0 & 53.2 & 25.6 & 0.4 & 1.8 & 100.0 \\
Sector & & & & & & \\
Manufacturing & 7.1 & 60.7 & 29.5 & 0.2 & 2.5 & 100.0 \\
Electricity, gas, water & - & 23.5 & 76.5 & - & - & 100.0 \\
Construction & 25.3 & 51.0 & 20.7 & 1.0 & 2.1 & 100.0 \\
Trade & 11.0 & 68.6 & 18.8 & 0.2 & 1.4 & 100.0 \\
Market services & 41.3 & 32.5 & 24.2 & 0.7 & 1.4 & 100.0 \\
Financial intermediation & 4.1 & 66.4 & 29.5 & - & - & 100.0 \\
All sectors & 19.0 & 53.2 & 25.6 & 0.4 & 1.8 & 100.0 \\
\hline
\end{tabular}

${ }^{\text {a }}$ Figures are weighted by employment. Source: Wage Dynamics Network survey. 
As noted earlier in Section 2, trade unions and employers' associations also report that firm-level agreements are most common in large firms and minimal in small firms. Profit margins are generally higher for larger firms and firms in the utilities and financial intermediation sectors, which allow them greater flexibility in giving performancebased compensation above the wage increases negotiated in the general and sectoral agreements. Also, union density is likely to be lower in smaller firms and in the services sector, which reduces the scope for sectoral agreements being applied by them.

\subsection{Adjustment of base wages to inflation}

The responses in the WDN survey to the question on whether firms had a policy of adapting changes in base wages to inflation are seemingly inconsistent with the institutional features of wage setting in Slovenia. As noted in Section 2, the general agreement negotiated by social partners in 2006 (the reference period for the survey) for workers in the private sector not covered by sectoral collective agreements provided for a inflation safeguard clause, and the sectoral agreements were required by law to set terms at least as favorable as those in the general agreement. Yet, as Table 3 shows, as much as 40 percent of the sample indicated that they did not apply inflation indexation policy to adjust base wages. The proportion indicating no inflation-indexation policy was high across all size groups and sectors, but was highest among firms with 50-199 workers and in construction and trade. Strangely, these two sectors also reported the lowest incidence of firm-level collective agreements.

While the survey responses reflect respondent bias, one can conjecture a few reasons for the seeming inconsistency. First, it is possible that the base wages negotiated in the sectoral agreements went up by more than the indexation amount suggested in the

Table 3 Slovenia: Policy of adjusting base wages to inflation by firm size and sector (Percent in each size group and sector) $^{a}$

\begin{tabular}{|c|c|c|c|c|c|c|}
\hline & \multicolumn{2}{|c|}{ Automatic } & \multicolumn{2}{|c|}{ Informal } & \multirow{2}{*}{$\begin{array}{c}\text { No inflation } \\
\text { indexation } \\
\text { policy }\end{array}$} & \multirow[t]{2}{*}{ Total } \\
\hline & $\begin{array}{c}\text { Past } \\
\text { inflation }\end{array}$ & $\begin{array}{l}\text { Expected } \\
\text { inflation }\end{array}$ & $\begin{array}{c}\text { Past } \\
\text { inflation }\end{array}$ & $\begin{array}{l}\text { Expected } \\
\text { inflation }\end{array}$ & & \\
\hline \multicolumn{7}{|l|}{$\begin{array}{l}\text { Firm size (number } \\
\text { of employees) }\end{array}$} \\
\hline 5 to 19 & 20.9 & 0.8 & 26.2 & 4.9 & 47.2 & 100 \\
\hline 20 to 49 & 18.5 & 3.5 & 31.2 & 4.5 & 42.3 & 100 \\
\hline 50 to 199 & 10.6 & - & 28.7 & 7.2 & 53.6 & 100 \\
\hline 200 or more & 25.3 & 4.2 & 35.6 & 4.6 & 30.3 & 100 \\
\hline All size groups & 20.9 & 2.6 & 31.9 & 5.1 & 39.5 & 100 \\
\hline \multicolumn{7}{|l|}{ Sector } \\
\hline Manufacturing & 18.5 & 3.7 & 37.4 & 4.3 & 36.2 & 100.0 \\
\hline Electricity, gas, water & 61.6 & - & 9.2 & 8.4 & 20.8 & 100.0 \\
\hline Construction & 7.9 & 3.0 & 36.1 & 4.9 & 48.2 & 100.0 \\
\hline Trade & 22.8 & 1.8 & 22.0 & 5.7 & 47.7 & 100.0 \\
\hline Market services & 24.8 & 0.5 & 32.9 & 6.1 & 35.7 & 100.0 \\
\hline Financial intermediation & 36.3 & 11.3 & 15.4 & 2.5 & 34.5 & 100.0 \\
\hline All sectors & 20.9 & 2.6 & 31.9 & 5.1 & 39.5 & 100.0 \\
\hline
\end{tabular}

${ }^{\text {a }}$ Figures are weighted by employment. Source: Wage Dynamics Network survey. 
general agreement. Second, it is possible that the respondents did not pay attention to the fact that the question referred to base wages rather than total gross wages. Since nominal total gross wages grew more rapidly than inflation because of reasons related to productivity growth and other performance considerations, it is possible that the respondents did not perceive inflation indexation as being relevant or binding for overall wage determination. Third, the respondents may have misinterpreted the guidelines for indexation in the general collective agreement. The safeguard clause for additional wage increases in 2006 was not triggered because actual inflation in end-December was less than projected ${ }^{16}$. Also, the general agreement for 2006-07 specified a particular rate of wage increase without any explicit reference to indexation ${ }^{17}$, and the safeguard clause related to inflation developments in 2006 was to take effect in 2007. Thus, these two aspects could have mistakenly led some respondents to believe that indexation of wages to inflation did not apply in 2006. Fourth, it may be that the respondents were influenced by the fact that, unlike in earlier years, the indexation mechanism in 2006 was not government imposed.

Another striking finding of the WDN survey is that of those who indicated inflation indexation of base wages a vast majority replied that wages were indexed to past inflation. The pattern was similar across all size groups and sectors. Once again, this response may have been influenced by the specific way that the indexation mechanism operated in Slovenia. As noted in Section 2, Slovenia moved away from backward indexation to forward-looking indexation in 2002, and agreements further included a safeguard clause for additional increase if actual inflation exceeded the projected or specified rate. The 2006 agreement did not explicitly include an indexation coefficient and figure for projected inflation but had a safeguard clause. This may have influenced respondents to interpret the framework as backward- looking indexation. It is difficult to decipher why indexation was considered informal by a sizeable percentage of the sample, because indexation was a key feature of collective agreements and there was a formal rule.

The survey responses to the question on the typical frequency of base wage changes due to inflation, shown in Table 4, is puzzling as well as seemingly inconsistent with the institutional arrangements for indexation. First, the percentage of respondents stating that they never adjusted base wages due to inflation (16.5 percent, Table 4 ) is much smaller than the percentage that claimed no inflation indexation policy (39.5 percent, Table 3). Second, we know from the discussion of collective agreements in Section 2 that the typical frequency of wage indexation from 1999 onward was two times a year. However, since the safeguard clause was not triggered in 2006, only one adjustment of basic wages took place in August that year. Thus, it is odd that one third of the sample claimed that base wages were adjusted to inflation once every two years or less frequently than once every two years. Perhaps, the respondents were referring to the duration for which the negotiated agreements were valid. The proportion rose with firm size (from 16.5 percent in firms with 5-19 workers to 41 percent in firms with 200 or more workers), and was highest in the utilities and financial intermediation sectors (about 48 percent in each).

Evidence of response errors is further demonstrated by the cross-tabulation of responses to the questions on inflation indexation policy and frequency of wage changes due to inflation (Table 5). Of those who had indicated that they had an automatic or 
Table 4 Slovenia: Frequency of adjustment of base wage to inflation by firm size and sector (Percent in each size group and sector) ${ }^{\mathrm{a}}$

\begin{tabular}{lcccccc}
\hline & $\begin{array}{c}\text { More than } \\
\text { once a year }\end{array}$ & Once a year & $\begin{array}{c}\text { Once every } \\
\text { two years }\end{array}$ & $\begin{array}{c}\text { Less frequently than } \\
\text { one every two years }\end{array}$ & Never & Total \\
\hline $\begin{array}{l}\text { Firm size (number } \\
\text { of employees) }\end{array}$ & & & & & & \\
5 to 19 & 18.8 & 42.9 & 3.1 & 13.4 & 21.9 & 100.0 \\
20 to 49 & 19.4 & 37.8 & 14.3 & 15.1 & 13.4 & 100.0 \\
50 to 199 & 13.1 & 41.9 & 9.7 & 23.1 & 12.2 & 100.0 \\
200 or more & 14.3 & 27.9 & 15.4 & 25.6 & 16.7 & 100.0 \\
All size groups & 15.6 & 34.8 & 11.7 & 21.4 & 16.5 & 100.0 \\
Sector & & & & & & \\
Manufacturing & 19.8 & 32.7 & 12.6 & 22.6 & 12.3 & 100.0 \\
Electricity, gas, water & 9.2 & 42.9 & 17.6 & 30.3 & - & 100.0 \\
Construction & 22.2 & 39.4 & 7.8 & 15.3 & 15.3 & 100.0 \\
Trade & 12.9 & 46.7 & 3.7 & 20.4 & 16.4 & 100.0 \\
Market services & 10.0 & 26.5 & 18.1 & 20.7 & 24.7 & 100.0 \\
Financial intermediation & 6.8 & 33.2 & 9.5 & 38.0 & 12.6 & 100.0 \\
All sectors & 15.6 & 34.8 & 11.7 & 21.4 & 16.5 & 100.0 \\
\hline a Figures are weighted by & & & & &
\end{tabular}

Figures are weighted by employment.

Source: Wage Dynamics Network survey.

informal inflation indexation policy, 16 percent responded that that they had never adjusted wages due to inflation. Furthermore, of those who indicated that they had no inflation indexation policy, nearly 60 percent stated that they adjusted base wages due to inflation once a year or more frequently. It may be that these firms did not see their action as wage indexation as they did not follow the automatic indexation rule specified in the collective agreement. Nevertheless, these seeming inconsistencies point to the absence of proper cross-checks of the answers by the survey data compilers and to the need for follow-up clarification of interpretation of the questions by the respondents.

\subsection{Downward wage rigidity}

The responses to the WDN survey questions aimed at assessing wage rigidity need to be interpreted with caution ${ }^{18}$. An extremely small proportion of firms answered that they had ever frozen or cut the base wages in the five years prior to the survey (below 3 percent in both cases). About three-fourths of the firms indicated that regulation or collective bargaining was of little or no relevance in preventing base wage cuts. Rather, the two most important reasons why base wage cuts were rare were the impact on work morale and the possibility that the most productive workers would leave as a consequence. In response to the questions about possible reactions of firms to possible demand and supply shocks, no firm indicated wage cuts as the most important factor for reducing costs. Furthermore, about two-thirds of the sample indicated that they had never used any measure to reduce labor costs.

As such, these responses could be seen as evidence of high downward wage rigidity in Slovenia but, when viewed against the economic climate during the five year reference window, we cannot take the survey responses as conclusive evidence. As Sila and Jesenko (2011) point out, the observed downward nominal wage rigidity can be 
Table 5 Slovenia: Inflation indexation policy and frequency of adjustment of base wages to inflation (Percent frequency of adjustment in each indexation policy category) ${ }^{a}$

\begin{tabular}{|c|c|c|c|c|c|c|}
\hline & \multicolumn{2}{|c|}{ Automatic } & \multicolumn{2}{|c|}{ Informal } & \multirow{2}{*}{$\begin{array}{c}\text { All categories } \\
\text { of inflation } \\
\text { indexation } \\
\text { policy }\end{array}$} & \multirow{2}{*}{$\begin{array}{c}\text { No inflation } \\
\text { indexation } \\
\text { policy }\end{array}$} \\
\hline & $\begin{array}{c}\text { Past } \\
\text { inflation }\end{array}$ & $\begin{array}{l}\text { Expected } \\
\text { inflation }\end{array}$ & $\begin{array}{c}\text { Past } \\
\text { inflation }\end{array}$ & $\begin{array}{l}\text { Expected } \\
\text { inflation }\end{array}$ & & \\
\hline More than once a year & 13.7 & 31.2 & 17.5 & 22.1 & 17.2 & 13.2 \\
\hline Once a year & 23.8 & 33.4 & 29.4 & 31.0 & 27.8 & 45.5 \\
\hline Once every two years & 13.8 & 1.4 & 17.7 & 1.1 & 14.2 & 7.8 \\
\hline $\begin{array}{l}\text { Less frequently than } \\
\text { once every two years }\end{array}$ & 21.0 & 32.4 & 24.6 & 40.4 & 25.0 & 15.9 \\
\hline Never & 27.8 & 1.7 & 10.8 & 5.5 & 15.8 & 17.7 \\
\hline Total & 100.0 & 100.0 & 100.0 & 100.0 & 100.0 & 100.0 \\
\hline
\end{tabular}

${ }^{a}$ Figures are weighted by employment. Source: Wage Dynamics Network survey.

explained by the absence of a business cycle downturn during the reference period. The WDN survey was conducted prior to the onset of the financial crisis and, as discussed in Section 3, the Slovene economy experienced robust GDP and productivity growth and a U-shaped inflation path during 2003-2007. Thus, there was little incentive for cutting or freezing base wages or, for that matter, total gross wages during this period. While base wages were partially indexed to inflation under general collective agreements, additional wage increases were negotiated in sectoral and firm-level collective agreements based on productivity and performance considerations. Indeed, as Figure 4 shows, reflecting the favorable economic trends, the proportion of private sector employees who received performance-related payments ("thirteenth month's pay" and Christmas bonus) increased from 20.6 percent in 2003 to a peak of 33 percent in $2007^{19}$. Had employers made efforts to cut base wages or total gross wages in this environment, they would likely have lost their most productive workers.

When faced with falling demand shock during the financial crisis, Slovene firms displayed flexibility in cutting labor costs to a significant degree. The adjustments were primarily in variable pay components and employment but not in base wages,

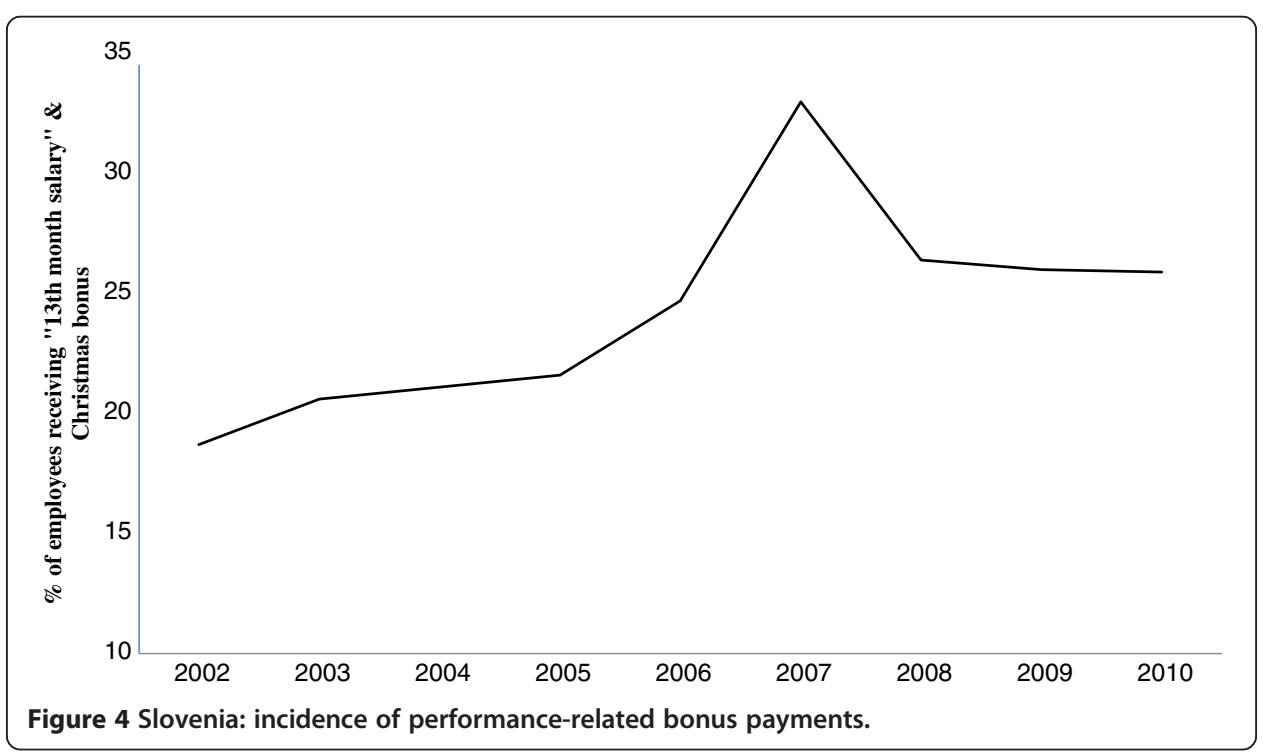


consistent with the provisions of the collective bargaining agreements and the constraint imposed by the level of the minimum wage. The proportion of private sector employees who received performance-related payments fell to about 26 percent in 2010-a decrease of nearly one-fifth from the 2007 level-and the average amounts of the payments were smaller. Because of the existence of flexible wage components, firms could manipulate these payments to lower total nominal gross wage without cutting base wages. In addition to cutting performance related wage payments, Slovene firms cut labor costs by reducing unpaid overtime work, placing workers on shorter-time work schedules, and laying off fixed-term and temporary workers ${ }^{20}$. Enterprise level collective agreements typically include the possibility of introducing shorter-hour work schedule. As noted earlier in footnote 13 in Section 3, private sector employment was cut back by 7.25 percent and another 12.7 percent of employees placed on shorter-time work schedules in 2009-2010.

Supporting evidence on the prevalence of flexible wage components in the form of performance-related bonus payments is provided by the WDN survey. As Table 6 shows, on average about 17.5 percent of the total wage bill in Slovene firms in the survey reference period (i.e., 2006) was allocated to bonuses associated with individual or company performance. Bonus payments were more important in small-sized firms, and in construction and trade sectors. The average share of both individual and company performance-related bonuses in the total wage bill was highest among firms employing 5 to 19 workers and fell as firm size increased. Firms in the trade sector paid bonuses related to both individual and company performance, whereas the construction sector tended to rely mainly on bonus payments related to individual performance.

Following Babecký et al. (2009, 2012), Sila and Jesenko (2011) treat indexation of base wages to inflation as a proxy for real wage rigidity and carry out an econometric exercise relating this variable to selected firm characteristics ${ }^{21}$. In the specifications for the

\begin{tabular}{lcc}
$\begin{array}{l}\text { Table } \mathbf{6} \text { Share of total wage bill comprised of bonuses related to individual and } \\
\text { company performance by size and sector } \\
\text { size group and sector, in percent) }\end{array}$ & $\begin{array}{c}\text { Individual performance } \\
\text { related bonus }\end{array}$ & $\begin{array}{c}\text { Company performance } \\
\text { related bonus }\end{array}$ \\
\hline $\begin{array}{l}\text { Firm size (number } \\
\text { of employees) }\end{array}$ & 12.0 & 10.0 \\
\hline 5 to 19 & 11.3 & 9.0 \\
20 to 49 & 11.1 & 5.8 \\
50 to 199 & 9.3 & 5.9 \\
200 or more & 10.4 & 7.1 \\
All size groups & & 5.3 \\
Sector & 8.1 & 7.5 \\
Manufacturing & 4.1 & 4.5 \\
Electricity, gas, water & 11.9 & 11.3 \\
Construction & 15.9 & 7.3 \\
Trade & 9.6 & 9.7 \\
Market services & 8.9 & 7.1 \\
Financial intermediation & 10.4 & \\
All sectors & & 5.3 \\
\hline
\end{tabular}

Source: Wage Dynamics Network survey. 
sample of euro zone countries, Sila and Jesenko find that after controlling for other firm characteristics, GDP growth and inflation, Slovenia had the highest probability of firms reporting indexation of base wages to inflation. In the specification restricted to Slovene firms, the probability of reporting base wage indexation is higher for firms with higher share of high-skilled blue-collar workers and for large firms. Also, contrary to expectations, the probability of reporting wage indexation is lower for firms with a non-firm level collective agreement compared to firms with a firm-level agreement.

The results of the econometric exercise is best seen as multivariate determinants of the response to the question on whether the enterprise had a policy to adapt changes in base wages to inflation ${ }^{22}$, rather than determinants of real wage rigidity. As noted in the previous section, the answers to this question were subject to serious response error, taking into account institutional arrangements for wage indexation in Slovenia as well as the WDN survey responses regarding the frequency of wage adjustments to inflation. General collective agreements covered all private sector employees in Slovenia for indexation of base wages to inflation. If all the survey responses were consistent with this institutional feature, the econometric exercise would be redundant because of lack of variability in the dependent variable. Still, wage indexation per se should not be taken as evidence of downward real wage rigidity. In Slovenia, the indexation of base wage to inflation was partial, thus allowing for a decrease in base wages in real terms in all years. The growth of total gross wages exceeded inflation because of additional wage increases linked to productivity gains and performance, and there was variation in annual developments in real gross wages.

\section{Conclusions}

An important conclusion of this paper is that the WDN survey findings on wagesetting behavior of firms have to be interpreted with caution and should not be used to draw definite conclusions about wage flexibility in Slovenia. The survey had critical shortcomings: the response rate was very low, the design of some key questions did not capture the prevailing institutional arrangements, questions may have been interpreted differently by different respondents, and answers to some questions were mutually inconsistent which suggested response errors and lack of proper cross-check by the survey administrators. In addition, it is likely that the survey responses were influenced by the prevailing economic environment. The survey was conducted at a time when the economy was booming and Slovenia had not experienced a downturn in the business cycle during the preceding decade.

Evidence indicates that a sizeable part of the enterprise wage bill comprises of performance related bonus payments that tend to be pro-cyclical in nature. In the years preceding the onset of the financial crisis, the proportion of private sector employees receiving performance-related payments was on an upward trend. However, faced with falling demand shock with the onset of the financial crisis in late-2008, Slovene firms displayed flexibility in cutting labor costs to a significant degree. Enterprises cut back on performance-related payments in terms of amounts as well as the number of employees receiving them, lowered paid overtime work, put employees on shorter-hours work schedule, and laid-off workers. The labor cost adjustment methods implemented by the enterprises were within the bounds of the collective wage bargaining 
arrangements and did not involve cuts in base wages. A cut in base wages was not an option following the large increase in the minimum wage in 2010, as the increase pushed the minimum wage well above the basic wages negotiated in some sectoral agreements, even for more demanding tasks. The government's minimum wage policy contributed to downward wage rigidity and worked against the other efforts aimed at fostering wage flexibility.

A number of steps have been taken in recent years to increase wage and labor market flexibility in Slovenia, though their impact is yet to be fully felt and many challenges remain. The Collective Agreement Act 2006 provided for collective agreements to be negotiated on a voluntary basis and the changes were to go into effect after a three-year transition period. Thus, a decrease in the proportion of employees covered by collective bargaining can be expected over time. The Employment Relationship Act was amended in 2007 with the aim of expanding the possibility of using flexible forms of employment (fixed-term employment), allowing for longer overtime work, and making termination of employment contracts easier (Institute of Macroeconomic Analysis and Development (IMAD) 2008).

Looking ahead, there is a need to examine how enterprises have adapted to the changes in the institutional aspects of wage-setting and employment relationships, and to conduct in-depth micro data-based analysis of the enterprise behavior prior to the crisis, during the crisis, and after the crisis. Unlike many other European countries, Slovenia did not participate in the follow-up WDN survey that was conducted in 2009 soon after the start of the financial crisis. Thus, a follow-up WDN style survey that takes into account the lessons from the 2008 survey and other follow-up surveys conducted elsewhere is desirable. It would be particularly important in the follow up survey to include questions on the role of the minimum wage in the setting of basic wages in sectoral collective agreements and its impact on the labor cost adjustment efforts of enterprises. For a comprehensive assessment of enterprise behavior and labor market outcomes, it is not sufficient to focus on existing firms. It would be worthwhile supplementing the survey for existing firms with a small survey of firms that have ceased operations in recent years.

\section{Endnotes}

${ }^{1}$ The sample also included Japan and the United States.

${ }^{2}$ The main findings are reported in Du Caju et al. (2008).

${ }^{3}$ See European Central Bank (2009a, b) for the main findings of the-firm level surveys. Detailed analyses of the firm-level surveys can be found in numerous WDN papers, which are cited in European Central Bank (2009b). Four of these papers appear in Labour Economics 19 (5), 2012.

${ }^{4}$ EIROnline reports union density of 41.3 percent in 2003 (European Industrial Relations Observatory On-line (EIROnline) 2004), 44 percent in 2007 (2009b), and approximately 40 percent in 2008 (2009a, 2010).

${ }^{5}$ In 2007, the share of temporary employment in total employment stood at 18.4 percent (Institute of Macroeconomic Analysis and Development (IMAD) 2008).

${ }^{6}$ Union confederations at the national level are deemed representative if their members cover at least 10 percent of the employees in the industries, businesses or 
professions. Unions are deemed representative in an industry, business or profession if they are either affiliated to a union confederation or cover at least 15 percent of the employees in an industry, business or profession.

${ }^{7}$ Given the focus of the paper, we do not discuss collective bargaining mechanisms in the public sector. See Institute of Macroeconomic Analysis and Development (IMAD) (2007b) for discussion of collective agreements in the public sector.

${ }^{8}$ The general agreement was used explicitly as a reference point in many sectoral collective agreements (e.g. the collective agreement for retail and wholesale trade). However, some collective agreements did not make any reference to the general collective agreement but provided terms at least as favorable (e.g., the collective agreement for the metal industries).

${ }^{9}$ Enterprises with 250 or more employees are classified as large enterprises, those with 50 to 249 employees are classified as medium-sized enterprises, and those with less than 50 employees are classified as small enterprises.

${ }^{10}$ Adjustment in August for expected inflation, and additional adjustment made in January if inflation exceeds forecast.

${ }^{11}$ See Surti (2010) for a detailed analysis of inflation in Slovenia in 2007-08.

12 The number of paid hours for overtime work plunged by 44.3 percent in 2009 . The share of overtime work in private sector wages was about 1.5 percent in 2008 and fell to 0.9 percent in 2009 (Institute of Macroeconomic Analysis and Development (IMAD) 2011).

${ }^{13}$ When the crisis hit Slovenia in the fourth quarter of 2008, the first reaction of companies was not to renew fixed-term contracts and to reduce other forms of flexible employment (Institute of Macroeconomic Analysis and Development (IMAD) 2009). A newspaper article (Delo, March 31, 2009) quoted a statement by the Minister of Labor, Family and Social Affairs that 6,000-7,000 jobs had been saved by the subsidy scheme to support shorter-hour work schedule. In 2009 and 2010, about 65,800 employed persons in 904 enterprises (accounting for 12.7 percent of employed workers and 1.6 percent of enterprises) were beneficiaries of the subsidy scheme for short-time work. Partial reimbursement to support paid leave for temporary period was provided to 946 enterprises for about 25,100 employed persons (accounting for 1.6 percent of enterprises and 3.8 percent of employed persons). In the total number of recipients for both subsidies, the largest proportion was in manufacturing enterprises (44 percent), followed by trade enterprises (18 percent). Within manufacturing activities, the metal industry included the largest share of its employees in the two schemes. Notwithstanding the anti-crisis measures, total employment in the private sector fell by 7.25 percent in the two-year period 2009-2010 (Institute of Macroeconomic Analysis and Development (IMAD) 2011).

${ }^{14}$ To facilitate meeting the Maastricht inflation criterion under ERM II, the general collective agreement for 2004-05 explicitly set down a guideline that real wage increases should lag productivity growth by at least 1 percentage point.

${ }^{15}$ Slovenia did not participate in the follow-up WDN survey conducted in 2009.

${ }^{16}$ As noted in Table 1, the general collective agreement for 2004-05 provided for additional wage increases in 2006 if inflation at end-December 2005 exceeded 2.9 percent. However, actual inflation at end-December 2005 was 2.3 percent.

${ }^{17}$ However, as noted in Section 2, projected inflation was taken into account by social partners in the determination of the specified rate of wage increase. 
${ }^{18}$ See Sila and Jesenko (2011) for a detailed analysis of the WDN survey evidence on downward wage rigidity in Slovenia.

${ }^{19}$ In 2006, the percentage of employees receiving performance-related bonus was highest in the utilities sector and financial intermediation (around 90 percent), and lowest in construction, distributive trades, and hotels and restaurants (below 20 percent) (Institute of Macroeconomic Analysis and Development (IMAD) 2007a).

${ }^{20}$ European Commission (2009) and OECD (2009) discuss and analyze the behavior of firms and discretionary changes in labor market policy in the EU and OECD countries in response to the economic downturn. The developments in Slovenia noted here are consistent with the cross-country finding of Bertola et al. (2012) that firms covered by collective wage agreements seeking to lower costs are more likely to do so by reducing the number of temporary employees than by reducing wages. European Central Bank (2009b) report that according to the 2009 follow-up survey the incidence of nominal wage freeze increased significantly during the financial crisis but the incidence of base wage cuts hardly increased. On this basis, the ECB concludes that downward wage rigidity was still prevalent in most European countries in the summer of 2009.

${ }^{21}$ Babecký et al. treat automatic indexation of base wages to inflation as a proxy for real wage rigidity, while Sila and Jesenko treat all manners of indexation of base wages to inflation (i.e., automatic as well as informal) as a proxy for real wage rigidity.

${ }^{22}$ Sila and Jesenko (2011) make an important contribution in this regard.

\section{Competing interests}

The IZA Journal of European Labor Studies is committed to the IZA Guiding Principles of Research Integrity. The authors declare that they have observed these principles.

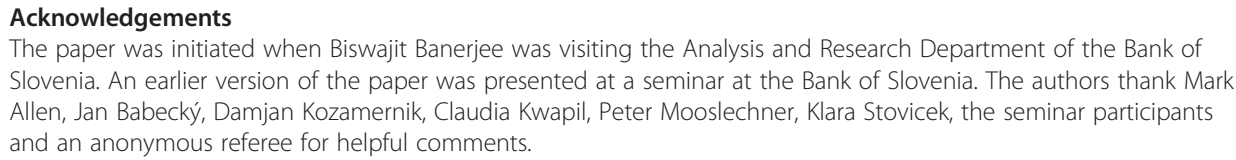

References

Aidt T, Tzannatos Z (2002) Unions and Collective Bargaining: Economic Effects in a Global Environment. The World Bank, Washington, D.C

Babecký J, Du Caju P, Kosma T, Lawless M, Messina J, Rõõm T (2009) Downward Nominal and Real Wage Rigidity: Survey Evidence from European Firms. European Central Bank Working Paper Series No. 1105. November http:// www.ecb.int/pub/pdf/scpwps/ecbwp1105.pdf

Babecký J, Du Caju P, Kosma T, Lawless M, Messina J, Rõõm T (2012) How do European firms adjust their labour costs when nominal wages are rigid? Labour Econ 19:792-801

Banerjee B, Shi H (2010) Determinants of Inflation in Slovenia on the Road to Euro Adoption. In: Bole V, Mackellar L (ed) From Tolar to Euro. Center of Excellence in Finance, Ljubljana

Bertola G, Dabusinskas A, Hoeberichts M, Izquierdo M, Kwapil C, Montornès J, Radowski D (2012) Price, wage and employment response to shocks: evidence from the WDN survey. Labour Econ 19:783-791

Bole V, Mramor D (2006) "Soft landing" in the ERM2: Lessons from Slovenia. In: Prašnikar J (ed) Competitiveness, Social Responsibility and Economic Growth. Nova, New York

Calmfors L, Driffill J (1988) Bargaining structure, corporatism, and macroeconomic performance. Econ Pol 3(6):13-61

Deutsche Bundesbank (2009) Wage setting in Germany — new empirical findings. Monthly Report. April, 17-29 http:// www.bundesbank.de/Redaktion/EN/Downloads/Publications/Monthly_Report_Articles/2009/2009_04_wage_setting. pdf?_blob=publicationFile

Driffill J (2006) The Centralization of Wage Bargaining Revisited. What have we learned? J Common Mark S 44(4):731-756 
Du Caju P, Gautier E, Momferatou D, Ward-Warmedinger M (2008) Institutional features of wage bargaining in 23 European countries, the US and Japan. European Central Bank Working Paper Series No. 974. December. http:// www.ecb.int/pub/pdf/scpwps/ecbwp974.pdf

European Central Bank (2009a) New survey evidence on wage setting in Europe. Monthly Bulletin. February, 69-83. http://www.ecb.int/pub/pdf/other/mb200902_pp69-83en.pdf

European Central Bank (2009b) Wage dynamics in Europe: Final report of the Wage Dynamics Network (WDN). Directorate General Research. December. http://www.ecb.int/home/pdf/wdn_finalreport_dec2009.pdf? 1776a5bd5665316534d194a0dda4861e

European Commission (2009) Slovenia: The partial subsidy of full time work. European Employment Observatory Review. Spring:106-109 http://www.eu-employment-observatory.net/resources/reviews/EN-EEOReviewSpring2009-3.pdf

European Foundation for the Improvement of Living and Working Conditions (Eurofound) (2007) Capacity building for social dialogue at sectoral and company level in Slovenia http://www.eurofound.europa.eu/pubdocs/2007/2213/ en/1/ef072213en.pdf

European Foundation for the Improvement of Living and Working Conditions (Eurofound) (2011) Extension of collective bargaining agreements in the EU http://www.eurofound.europa.eu/pubdocs/2011/54/en/1/EF1154EN.pdf

European Industrial Relations Observatory On-line (EIROnline) (2004) Trade union membership 1993-2003 http://www. eurofound.europa.eu/eiro/2004/03/update/TN0403105U.htm

European Industrial Relations Observatory On-line (EIROnline) (2009a) Trade union membership 2003-2008 http://www. eurofound.europa.eu/eiro/studies/tn0904019s/tn0904019s.htm

European Industrial Relations Observatory On-line (EIROnline) (2009b) Slovenia: Industrial relations profile http://www. eurofound.europa.eu/eiro/country/slovenia.htm

European Industrial Relations Observatory On-line (EIROnline) (2009c) Decline in employer organisations' density rates http://www.eurofound.europa.eu/eiro/2008/09/articles/S108090391.htm

European Industrial Relations Observatory On-line (EIROnline) (2010) Trade union strategies to recruit new groups of workers - Slovenia http:/www.eurofound.europa.eu/eiro/studies/tn0901028s/si0901029q.htm

European Industrial Relations Observatory On-line (EIROnline) (2013) Slovenia: Industrial relations profile http://www. eurofound.europa.eu/eiro/country/slovenia_3.htm

Institute of Macroeconomic Analysis and Development (IMAD) (2004) Collective bargaining and coverage and extension procedures. Slovenian Economic Mirror X (2). February http://www.umar.gov.si/fileadmin/user_upload/ publikacije/eo/2004/og0204/ang/aidr.pdf

Institute of Macroeconomic Analysis and Development (IMAD) (2006) Autumn Forecast of Economic Trends. Ljubljana http://www.umar.gov.si/uploads/media/abs_aforecast_2006.pdf

Institute of Macroeconomic Analysis and Development (IMAD) (2007a) Slovenian Economic Mirror XIII (2). February http://www.umar.gov.si/fileadmin/user_upload/publikacije/eo/2007/og0207/ang/em0207.pdf\#8

Institute of Macroeconomic Analysis and Development (IMAD) (2007b) Wages Productivity and Competitiveness. Economic Issues 2007. Ljubljana, pp 43-72 http://www.umar.gov.si/fileadmin/user_upload/publikacije/izzivi/AtrgDela.pdf

Institute of Macroeconomic Analysis and Development (IMAD) (2008) Challenges of the Labour Market from the Aspect of Flexicurity. Economic Issues 2008. Ljubljana, pp 95-133 http://www.umar.gov.si/fileadmin/user_upload/ publikacije/izzivi/2008/ang/El2008_poglavje4.pdf

Institute of Macroeconomic Analysis and Development (IMAD) (2009) Impact of the Economic Crisis on the Labour Market in Slovenia. Economic Issues 2009. Ljubljana http://www.umar.gov.si/fileadmin/user_upload/publikacije/ izzivi/2009//m09.pdf

Institute of Macroeconomic Analysis and Development (IMAD) (2011) Impact of the crisis on the labour market and key challenges. Economic Issues 2011. Ljubljana, pp 51-85

Institute of Macroeconomic Analysis and Development (IMAD) (2012) Labour Market Movements. Economic Issues 2012. Ljubljana, pp 63-98

Kézdi G, Kónya I (2009) Wage setting in Hungary: evidence from a firm survey. MNB Bulletin. October: 20-26 http:// english.mnb.hu/Root/Dokumentumtar/ENMNB/Kiadvanyok/mnben_mnbszemle/ mnben_mnb_bulletin_oktober_2009/kezdi-konya_2009_okt_en.pdf

Montornès J, Sauner-Leroy JB (2009) Wage-setting behavior in France: Additional evidence from an ad-hoc survey. European Central Bank Working Paper Series No. 1102. October [http://www.ecb.int/pub/pdf/scpwps/ecbwp1 102.pdf]

OECD (2009) Addressing the Labour Market Challenges of the Economic Downturn: A Summary of Country Responses to the OECD-EC Questionnaire http://www.oecd.org/dataoecd/15/29/43732441.pdf

OECD.StatExtracts http://stats.oecd.org/Index.aspx?DataSetCode=UN_DEN

Sila U, Jesenko M (2011) Downward Wage Rigidity in Slovenia: evidence from a survey of firms. Prikazi in Analize 4/ 2011, Bank of Slovenia

Surti J (2010) What drives inflation in Slovenia? In: Bole V, Mackellar L (ed) From Tolar to Euro. Center for Excellence in Finance, Ljubljana

Vodopivec M (2010) The role of collective bargaining agreements on wage determination in Slovenia: evidence from the WDN survey. Unpublished paper. Bank of Slovenia, Ljubljana

$10.1186 / 2193-9012-2-9$

Cite this article as: Banerjee et al:: Wage setting in Slovenia: interpretation of the Wage Dynamics Network

(WDN) survey findings in an institutional and macroeconomic context. IZA Journal of European Labor Studies 2013, $2: 9$ 